\title{
TYÖUUPUMUKSESTA TOIPUMISEN YKSILÖLLISET POLUT
}

\section{Monimenetelmällinen tapaustutkimus kuntoutusintervention pitkäaikaisvaikutuksesta}

\section{Johdanto}

Työuupumus: käsite ja hoito

Yleisimmin käytössä olevan määritelmän mukaan työuupumuksella tarkoitetaan kroonista työperäistä stressitilaa, joka ilmenee uupumusasteisena väsymisenä, kyynistymisenä sekä ammatillisen itsetunnon heikkenemisenä (Kalimo ym. 2006; Maslach ym. 2001; Näätänen ym. 2003). Työuupumus syntyy työn vaatimustekijöiden sekä työntekijän yksilöllisten tavoitteiden, voimavarojen ja selviytymiskeinojen välisessä vuorovaikutuksessa silloin, kun niiden välillä ilmenee ristiriitaa (Maslach ym. 2001). Työuupumus on sekä kansallisesti että kansainvälisesti merkittävä ongelma, joka uhkaa väestön terveyttä ja työkykyä (Ahola \&t Hakanen 2014). Kansanterveyslaitoksen keräämän Terveys 2000 -aineiston mukaan työikäisistä suomalaisista 27,9 prosenttia raportoi jonkinasteisia uupumusoireita ja 2,5 prosentilla oireet ovat vakava-asteisia (Ahola \&t Hakanen 2014). Tämän jälkeen vuonna 2011 tehdyn Terveys-tutkimuksen mukaan työuupumusoireilu oli jonkin verran vähentynyt työikäisillä (Suvisaari ym. 2012).

Työuupumusta hoidetaan monin eri keinoin, joista kuntoutusinterventiot ovat yksi mahdollinen hoitokeino. Työuupumusinterventiot voidaan tyypillisesti jaotella yksilökeskeisiin, työorganisaatioon keskittyviin tai molemmat näkökohdat huomioiviin (Hätinen 2008; Maslach ym. 2001). Suomessa merkittävässä roolissa ovat Kelan kuntoutuskurssit, joiden avulla pyritään tukemaan uupumusoireista kärsivien henkilöiden työ- ja toimintakykyä ja jotka sijoittuvat siten pääasiallisesti yksilökeskeisten interventioiden piiriin (Kansaneläkelaitos 2008). Työuupumuksen takia toteutettujen kuntoutusinterventioiden vaikuttavuudesta on jonkin verran tutkimusnäyttöä (Awa ym. 2010; Hätinen ym. 2007), mutta tutkimuksellisia haasteita aiheuttavat muun muassa pitkäaikaisten seurantojen puute, kuntoutujien yksilölliset oirekuvat sekä erot käytetyissä interventio- ja tutkimusmenetelmissä (Awa ym. 2010; Hätinen ym. 2009).

Olemassa olevan tutkimustiedon mukaan työuupumuksesta toipumiseen näyttäisivät olevan yhteydessä sekä ympäristö- että yksilötekijät. Tällaisia tekijöitä ovat esimerkiksi hallinnan tunteen lisääntyminen ja vähentyneet aikapaineet työssä (Hätinen 2008; Hätinen ym. 2009). Työuupumuskuntoutujien toipumisprosessien on kuitenkin todettu olevan yksilöllisiä, eikä kuntoutus tehoa kaikkiin henkilöihin tai uupumusoireisiin samalla tavalla (Hätinen ym. 2009 ja 2013). Aihetta tulisikin tutkia kattavammin hyödyntämällä yhtäaikaisesti sekä laadullisia että määrällisiä tutkimusmenetelmiä. Laadullisten menetelmien avulla kuntoutujien yksilöllinen kokemus 
ja yksilöitä yhdistävät sekä toisaalta erottavat tekijät on mahdollista saada esille monipuolisemmin kuin määrällisessä tutkimuksessa, jonka muuttujakeskeinen lähestymistapa saattaa antaa harhaanjohtavan tasapäisen kuvan tutkittavasta aineistosta (ks. Mäkikangas Et Kinnunen 2016). Toisin sanoen, kun jotkut yksilöt hyötyvät kuntoutusinterventiosta ja joillakin toisilla työuupumusoireilu jopa lisääntyy, tämä näyttäytyy koko aineistoa määrällisesti analysoitaessa usein tutkittavien ilmiöiden - tässä tapauksessa työuupumusoireiden - muuttumattomuutena ajassa.

Käsillä olevassa tutkimuksessa hyödynnetään sekä laadullisia että määrällisiä menetelmiä, mitä voidaan pitää tutkimuksen kiistattomana ansiona sen tuottaman monipuolisen tiedon takia. Monimenetelmällinen tutkimusote voi kuitenkin tuottaa osin ristiriitaista tietoa esimerkiksi siten, että työuupumuksen määrällinen arviointimenetelmä ja toisaalta kuntoutujan yksilöllinen kokemus tarjoavat keskenään erilaista tietoa työuupumuksen kehityksestä. Tällainenkin tieto kuitenkin lisäisi ymmärrystä työuupumuksesta toipumisen yksilöllisestä ja monimuotoisesta prosessista ja osaltaan auttaisi myös jatkotutkimusten suunnittelussa ja kuntoutusinterventioiden kehittämisessä.

\section{Toimijuus työuupumuskuntoutuksessa}

Kuntoutustieteessä ja -tutkimuksessa on alettu painottaa aktiivisen toimintakyvyn merkitystä kuntoutumiselle (Järvikoski \&t Härkäpää 2011). Aktiivista toimintakykyä voidaan arvioida muun muassa toimijuuden käsitteen kautta, joka soveltuu hyvin myös työuupumuksesta toipumisen tarkasteluun ja sen ymmärtämiseen (Salminen ym. 2015). Yksi tunnetuimmista toimijuutta kuvaavista teorioista on Albert Banduran (2000) sosiokognitiivinen malli, joka määrittelee toimijuuden henkilökohtaisen, läheis- ja kollektiivisen toimijuuden kautta (ks. myös Järvikoski ym. 2015a). Kaikki toimijuuden muodot ovat olennaisia työuupumuksesta toipumisessa (Salminen ym. 2015), mutta koska tässä tutkimuksessa käsitellään yksilökeskeistä työuupumuskuntoutusta, painopiste on erityisesti henkilökohtai- sessa toimijuudessa. Banduran (2000) mukaan yksilön voidaan sanoa ilmentävän henkilökohtaista toimijuutta, kun hän luottaa omiin kykyihinsä ja vaikutusmahdollisuuksiinsa sekä toimii omien tavoitteidensa mukaisesti.

Keskeisenä henkilökohtaisen toimijuuden ilmentäjänä voidaan tarkastella yksilön pystyvyysuskoa eli yksilön luottamusta omiin kykyihinsä ja mahdollisuuksiinsa (Bandura 2000, 2012). Pystyvyysuskoa ja toimijuutta käytetään tutkimuskirjallisuudessa myös osittain rinnakkaisina käsitteinä. Henkilökohtainen toimijuus ilmenee yksilön aktiivisena toimintana, ja sen yksi merkittävä osatekijä on pystyvyysusko. Henkilökohtaisen toimijuuden keskeiset piirteet ovat toiminnan tarkoituksellisuus, tulosten ennakointi, itsesäätely toiminnan toteuttamiseksi ja itsereflektio (Bandura 2006). Yksilön pysyvyysuskolla sekä toisaalta esimerkiksi itsereflektiolla voidaan nähdä olevan suuri merkitys työuupumuksesta toipumisessa, sillä yksilö kykenee terveytensä eheytymisen myötä sekä tarkastelemaan omaa toimintaansa että toimimaan sellaisilla tavoilla, jotka edelleen edistävät hyvinvointia. Yksilökuntoutuksessa on mahdollista vaikuttaa työuupumuskuntoutujan ajatuksiin, jotka koskevat hänen selviytymiskeinojaan, palautumista ja työn suhdetta muuhun elämään, sekä pohtia keinoja näihin asioihin vaikuttamiseksi. Täten kuntoutujien henkilökohtainen toimijuus on keskeisesti intervention kohteena ja myös tämän tutkimuksen keskiössä. On kuitenkin tärkeää ottaa huomioon, että henkilökohtaisen toimijuuden vahvistumiseen tai heikkenemiseen vaikuttavat yksilön lisäksi myös toimintaympäristön tuki sekä rajoitteet (Järvikoski \&t Härkäpää 2011). Henkilökohtainen toimijuus rakentuu siis kehämäisessä vuorovaikutuksessa ympäristön sekä yksilön oman toiminnan ja tulkintojen kanssa.

Kuntoutuksen kannalta olennaista on huomata, että henkilökohtainen toimijuus ei ole yksilön muuttumaton ominaisuus, vaan siihen on mahdollista vaikuttaa (Järvikoski \&t Härkäpää 2011; Järvikoski ym. 2015a). Tämän vuoksi kuntoutujien omatoimisuuden ja aktiivisuuden lisääminen on yksi Kelan Työuupumus-kuntoutuskurssien keskeisistä tavoitteis- 
ta (Kansaneläkelaitos 2008). Myös tutkimukset antavat viitteitä siitä, että toimijuudella on merkittävä rooli työuupumuksesta toipumisessa. Esimerkiksi Salminen ym. (2015) havaitsivat, että toipumisprosessissa keskeistä oli kuntoutujien oivallus siitä, että he pystyvät itse vaikuttamaan merkittävällä tavalla omaan hyvinvointiinsa. Toipumisprosessin myötä kuntoutujat oppivat hakemaan aktiivisesti apua, tunnistamaan paremmin omia rajojaan ja tarpeitaan sekä hyväksymään itsensä. Lloyd ym. (2013) havaitsivat puolestaan tutkimuksessaan, että hyväksymis- ja omistautumisterapiaan pohjautuvan ryhmäintervention myötä tapahtunut psykologisen joustavuuden lisääntyminen vähensi uupumusoireilua. Psykologinen joustavuus on sisällöltään rinnastettavissa henkilökohtaiseen toimijuuteen, ja tutkimustulos antaa osaltaan viitteitä siitä, että toimijuuteen pystytään vaikuttamaan interventioiden avulla.

Suomessa toimijuuden eri muotoja on tutkittu aiemmin lääkinnällisen kuntoutuksen yhteydessä määrällisiä menetelmiä hyödyntäen, ja niiden on havaittu olevan yhteydessä kuntoutuksen tuloksellisuuteen (ks. esim. Järvikoski ym. 2013; Järvikoski ym. 2015b). Työuupumuskuntoutuksen alalla toimijuustutkimusta ei kuitenkaan ole juuri tehty, vaan vaikuttavuustutkimukset ovat keskittyneet pääasiassa interventioiden tuloksellisuuden tutkimiseen määrällisiä muuttujia hyödyntäen. Muutamat työuupumuskuntoutujien toipumisprosessia kuvaavat sekä määrälliset että laadulliset tutkimukset ovat sivunneet henkilökohtaiseen toimijuuteen liittyviä tekijöitä ja havainneet ne merkityksellisiksi uupumuksesta toipumisen kannalta (Bernier 1998; Fjellman-Wiklund ym. 2010; Hätinen ym. 2007; Lloyd ym. 2013; Salminen ym. 2015).

Käsillä olevan tutkimuksen tarkoituksena on jatkaa tätä tutkimussuuntaa ja selvittää tarkemmin henkilökohtaisen toimijuuden merkitystä työuupumuskuntoutujien toipumisprosessissa pitkällä aikavälillä. Keskittyminen henkilökohtaiseen toimijuuteen on perusteltua, sillä työssäkäyvien, aikuisten ihmisten toimintakyky ja vaikutusmahdollisuudet omaan elämäänsä ovat yleisesti ottaen hy- vät (verrattuna esimerkiksi Kelan tukemien lääkinnällisten laitoskuntoutusten kohderyhmiin). Työhön liittyviä rakenteellisia tekijöitä tai kollektiivisia toimijuuden muotoja ei kuitenkaan jätetä huomiotta, vaan tarkoituksena on kartoittaa, kuinka henkilökohtainen toimijuus rakentuu suhteessa näihin tekijöihin.

\section{Tutkimuksen tavoite ja tutkimuskysymykset}

Tutkimuksen tarkoituksena on pitkäaikaisen seurannan ja tapaustutkimuksellisen otteen avulla selvittää yksityiskohtaisesti työuupumuksesta toipumisen kehityspolkuja ja niihin yhteydessä olevia tekijöitä. Erityisenä kiinnostuksen kohteena on työuupumuskuntoutujien henkilökohtainen toimijuus ja sen mahdollinen vaikutus heidän toipumiseensa. Tutkimuskysymykset ovat seuraavat:

1) Miten kuntoutujien työuupumus kehittyy kuntoutusjakson jälkeen? Ovatko kuntoutuksen myönteiset vaikutukset pysyviä vai uusiutuuko työuupumus?

2) Mitkä tekijät edistävät kuntoutujien toipumista tai johtavat uupumuksen uusiutumiseen?

3) Miten kuntoutujien toimijuutta voidaan määritellä aineistosta? Tapahtuuko toimijuuden asteissa muutoksia kuntoutuksen myötä ja kytkeytyykö toimijuus työuupumusoireissa tapahtuneisiin muutoksiin?

\section{Tutkimuksen toteutus}

\section{Aineisto}

Tutkimus on jatkoa Työuupumuksesta toipumisen vaiheet -tutkimushankkeelle, joka toteutettiin Jyväskylän yliopiston psykologian laitoksen ja Kuntoutus Peurungan yhteisprojektina syksyllä 2012. Tutkimushankkeelle myönsi luvan Jyväskylän yliopiston eettinen toimikunta, ja hankkeen aineisto kerättiin kolmelta Peurungassa elo-syyskuun 2012 aikana järjestetyltä, Kelan tukemalta työuupuneiden Virveli-kuntoutuskurssilta (ks. Salminen ym. 2015; Kuntoutus Peurunka 2010). Kuntoutus- 
kurssien tavoitteena oli edistää työuupumuksesta toipumista, auttaa löytämään keinoja, joiden avulla kuntoutujien työssä jaksaminen parantuisi, sekä kohentaa kuntoutujien elämänhallintaa ja lisätä sosiaalista osallistumista (Kansaneläkelaitos 2008; Kuntoutus Peurunka 2010). Kuntoutus muodostui kahdesta Peurungassa toteutetusta jaksosta: kymmenen vuorokauden perusjaksosta ja viiden vuorokauden seurantajaksosta. Perus- ja seurantajakson välinen aika oli enimmillään seitsemän kuukautta, jonka aikana kuntoutuja suoritti itsenäisesti sovittuja välitehtäviä. Virveli-kursseilla ohjelmaa oli yhteensä 70 tuntia, josta ryhmämuotoisen ohjelman osuus oli 59 tuntia ja yksilöllisen ohjelman osuus 11 tuntia (Kuntoutus Peurunka 2010). Kuntoutuskurssit toteutti moniammatillinen tiimi, johon kuuluivat muun muassa lääkäri, psykologi ja fysioterapeutti.

Tutkittavien vointia kartoitettiin ennen kuntoutuksen perusjaksoa sekä seurantajakson alussa. Alkuperäiseen tutkimushankkeeseen osallistumisen kriteerinä oli, että kuntoutujan työuupumus oli vähentynyt kuntoutuksen seurantajakson alkuun mennessä vähintään yhden luokka-asteen verran (lievä, kohtalainen, vakava uupumus tai ei uupumusta) joko BBI-15:n (Bergen Burnout Indicator 15; Näätänen ym. 2003) kokonaispistemäärän tai jonkin työuupumuksen oireulottuvuuden osapistemäärien osalta. Yhteensä 23 kuntoutujasta 15 täytti tämän kriteerin ja heistä kolme kieltäytyi tutkimukseen osallistumisesta. Haastatelluista 12 henkilöstä 11 valikoitui alkuperäiseen tutkimukseen BBI-15:n kokonaispisteiden perusteella ja yksi oireulottuvuuden osapistemäärän perusteella (uupumusasteinen väsymys). Laadullinen haastatteluaineisto kerättiin siten 12 henkilöltä kuntoutuskurssin seurantajakson lopussa loka-, marras- ja joulukuun 2012 aikana (Salminen ym. 2015). Puolistrukturoidut haastattelut pohjautuivat neljään ennalta määriteltyyn teemaan: työuupumuksen tausta, nykyhetki, kokemus kuntoutuksesta ja näkemykset tulevaisuudesta. Haastatteluiden yhteydessä vastaajilta tiedusteltiin halukkuutta osallistua samaa aihepiiriä käsittelevään seurantatutkimukseen.
Kaikki vastaajat olivat halukkaita ja antoivat käyttöön sähköpostiosoitteensa.

Seurantatutkimus toteutettiin vuonna 2014 ja sen tarkoituksena oli selvittää, millaisia yksilöllisiä toipumisprosesseja aineistosta on löydettävissä 1,5 vuotta kuntoutuksen päättymisen jälkeen ja kuinka kuntoutujat itse kokevat toipumisprosessinsa sekä siihen vaikuttaneet tekijät. Aineisto kerättiin keväällä 2014 sähköisellä kyselylomakkeella. Lomake sisälsi BBI-15-kyselyn, jonka lisäksi vastaajien kokemuksia nykytilanteestaan ja kuntoutuksesta kartoitettiin sekä strukturoitujen että avoimien kysymysten avulla. Kysely lähetettiin sähköpostitse 12 alkuperäiselle tutkittavalle, joista yhdeksän täytti kyselyn määräaikaan mennessä. Vastaamatta jättäneistä henkilöistä kaksi oli aineiston keräämisaikaan lomalla ja yksi jäi tavoittamatta. Tutkittavien keski-ikä oli 54 vuotta ja heistä kahdeksan oli naisia. Tutkittavat olivat kotoisin eri puolilta Suomea ja he edustivat eri ammattialoja. Seurantatutkimuksen toteuttamisen aikaan yksi tutkittava työskenteli osa-aikaisesti, yksi oli työtön ja muut työskentelivät kokoaikaisesti.

Tässä artikkelissa tarkastelun kohteena on yhdeksän tutkittavaa, joilta oli käytettävissä sekä vuonna 2012 kerätty tutkimustieto (työuupumusinventaari ja haastattelutieto) että vuonna 2014 kerätyn seurantakyselyn tulokset. Ensimmäinen tutkimusongelma koskee vastaajien työuupumusoireissa tapahtuneita muutoksia. Tätä arvioitiin BBI-15:n pistemäärissä vuosien 2012-2014 aikana tapahtuneiden muutosten avulla sekä hyödyntämällä vastaajien seurantakyselyssä kuvaamia kokemuksia uupumuksensa vakavuustasosta ja sen muutoksista. Toisena tutkimusongelmana oli löytää tekijöitä, jotka kuvaisivat työuupumuksesta toipumista tai sen mahdollista uusiutumista, jotta pitkän aikavälin toipumisprosessia olisi mahdollista ymmärtää paremmin. Näitä kuvailevia tekijöitä etsittiin sekä vuonna 2012 kerätystä haastatteluaineistosta että vuonna 2014 toteutetusta seurantakyselystä. Erityisenä kiinnostuksen kohteena oli kuntoutujien toimijuus ja sen mahdollinen yhteys työuupumuksesta toipumiseen. 


\section{Tutkimusmetodit}

Tutkimusaineiston analyysissa hyödynnettiin sekä määrällisiä että laadullisia menetelmiä. Tämä monimenetelmällinen lähestymistapa (engl. mixed method) mahdollisti suhteellisen pienen otoksen kattavamman ja monipuolisemman analyysin tapaustutkimuksen periaatteiden mukaisesti (Tuomi \&t Sarajärvi 2009). Työuupumusoireiden määrällisenä mittarina tutkimuksessa käytettiin BBI15-kyselyä (Näätänen ym. 2003), jota arvioitiin yksilötasolla oireiden keskiarvoina ja niiden muutoksina. Työuupumuksesta toipumista edistäneitä tekijöitä tarkasteltiin yksittäisten strukturoitujen kysymysten avulla, ja tulokset raportoitiin frekvensseittäin. Haastatteluaineistoa sekä seurantakyselyn avoimia vastauksia tutkittiin puolestaan laadullisen sisällönanalyysin avulla (Tuomi \& Sarajärvi 2009). Sisällönanalyysissa ei ole olemassa absoluuttisen oikeita tai vääriä tulkintoja, minkä vuoksi analyysin laadun varmistamiseksi aineistosta ja siitä tehdyistä johtopäätöksistä käytiin keskusteluja kirjoittajien kesken, jotka ovat työpsykologian ja työuupumuskuntoutuksen asiantuntijoita.

Työuupumuksen määrällisenä mittarina käytetty BBI-15-kyselylomake on validoitu menetelmä, joka on Suomessa yleisesti käytössä sekä kliinisessä työssä että tutkimuksessa (Näätänen ym. 2003). Korkeampi kokonaispistemäärä BBI-15:ssä viittaa vakavampaan uupumukseen. Kokonaispistemäärän mukaan vastaajat voidaan luokitella neljään eri luokkaan: ei uupumusta, lievä uupumus, kohtalainen uupumus ja vakava uupumus. Lisäksi sama luokittelu voidaan tehdä erikseen kolmen eri oireulottuvuuden eli uupumusasteisen väsymyksen, kyynistymisen ja ammatillisen itsetunnon heikentymisen osalta.

BBI-15:n lisäksi työuupumuksesta toipumista arvioitiin vastauksista seuraaviin seurantakyselyn avoimiin kysymyksiin: "Ovatko työuupumusoireet lisääntyneet/vähentyneet kuntoutuksen jälkeen? Jos ovat, miksi?”, "Mitä positiivisia/negatiivisia muutoksia työssäsi on tapahtunut kuntoutuksen päättymisen jälkeen?" ja "Miten työssä tapahtuneet muutokset ovat vaikuttaneet työhyvinvointiisi?"
Tutkittavien omien kertomusten perusteella tehty luokittelu ei ollut täysin yksiselitteistä, sillä useimmat vastaajat löysivät nykyisestä tilanteestaan sekä hyviä että huonoja puolia. Tutkittavien kertomukset nykyisestä voinnistaan auttoivat kuitenkin täydentämään BBI15:n luokittelutietoa ja analysoimaan vastaajien toipumisprosessia.

Sekä haastatteluaineistoa että seurantakyselyn avoimia vastauksia tutkittiin sisällönanalyysin keinoin. Sisällönanalyysi on tutkimusmenetelmä, jossa valmiita tekstiaineistoja tarkastellaan sisältöä eritellen, tiivistäen ja luokitellen (Tuomi \&t Sarajärvi 2009). Sisällönanalyysin erityisenä kiinnostuksen kohteena olivat kuntoutujien toimijuus ja sen merkitys työuupumuksesta toipumisessa. Näiltä osin lähestymistapa oli abduktiivinen eli aiempaa teoriaa hyödyntävä (Tuomi \&t Sarajärvi 2009). Taustateoriana ja lähtökohtana analyysille toimi Banduran $(2000,2006)$ henkilökohtaisen toimijuuden käsite. Tarkoituksena oli selvittää, miten toimijuus näkyi tutkittavien haastatteluissa sekä seurantakyselyn vastauksissa, oliko toimijuudessa tapahtunut muutoksia ja oliko toimijuus yhteydessä työuupumusoireissa tapahtuneisiin muutoksiin. Sisällönanalyysi noudatti mallia, jossa aineistoa luokiteltiin teoreettiseen viitekehykseen sopiviksi teemoiksi ja näitä yhdisteltiin yläkategorioiksi (Tuomi \&t Sarajärvi 2009).

Sisällönanalyysin ensimmäinen päävaihe oli litteroitujen haastatteluaineistojen sekä seurantakyselyjen avointen vastausten läpi lukeminen. Tässä vaiheessa yksittäisten tutkittavien vastauksista lähdettiin ensin erottelemaan parempaan vointiin/työuupumuksesta toipumiseen sekä voinnin heikentymiseen/ työuupumuksen uusiutumiseen liittyviä tekijöitä. Kategorisointi oli aluksi kaksijakoinen, mutta tähän lisättiin myös ambivalentit tekijät, jotka eivät olleet puhtaasti myönteisiä tai kielteisiä. Seuraavaksi näin luokitelluista tekijöistä etsittiin vastaajien toimijuutta kuvaavia asioita. Toimijuuden karkeana määrittelynä olivat Banduran (2006) mallia mukaillen kuntoutujien aktiiviset teot ja muutokset sekä tarkempina esimerkkikriteereinä 
Taulukko 1. Vastaajien työuupumuksessa tapahtuneet muutokset 1,5 vuoden seurannassa (kriteereinä BBI-15 ja oma kokemus).

\begin{tabular}{|llll|}
\hline \multicolumn{2}{|c|}{ Vuosi 2012 } & & Vuosi 2014 \\
\hline $\begin{array}{l}\text { BBI-15 ennen } \\
\text { kuntoutusta }\end{array}$ & $\begin{array}{l}\text { BBI-15 kuntoutuksen } \\
\text { seurantajaksolla }\end{array}$ & $\begin{array}{l}\text { BBI-15 } \\
\text { seurantajaksolla }\end{array}$ & Oma \\
Ei uupumusta & Ei uupumusta & Ei uupumusta & Ei-uupunut ${ }^{1}$ \\
Lievä uupumus & Ei uupumusta & Vakava uupumus & Uupunut \\
Kohtalainen uupumus & Ei uupumusta & Ei uupumusta & Ei-uupunut ${ }^{1}$ \\
Kohtalainen uupumus & Ei uupumusta & Ei uupumusta & Ei-uupunut ${ }^{1}$ \\
Kohtalainen uupumus & Ei uupumusta & Lievä uupumus & Ei-uupunut \\
Vakava uupumus & Ei uupumusta & Lievä uupumus & Ei-uupunut \\
Vakava uupumus & Lievä uupumus & Kohtalainen uupumus & Uupunut \\
Vakava uupumus & Lievä uupumus & Vakava uupumus & 2 \\
Vakava uupumus & Kohtalainen uupumus & Kohtalainen uupumus & Uupunut \\
\hline 1 Toipunut, ${ }^{2}$ Uudestaan uupunut, ${ }^{3}$ Kovia kokenut, mutta positiiviseen keskittyvä & \\
\hline
\end{tabular}

muun muassa avun hakeminen, itsereflektio, muutokset työn teossa tai vapaa-ajan vietossa sekä tulevaisuusodotukset uupumuksesta toipumisen osalta.

Sisällönanalyysin toisessa vaiheessa yksittäisten tutkittavien vastauksista tehtyjä luokitteluja verrattiin toisiinsa. Näistä etsittiin yhdistäviä ja erottavia tekijöitä, ja samankaltaisia luokituksia yhdisteltiin yläkategorioiksi (esimerkiksi työn stressitekijöiden lisääntyminen, sosiaalinen tuki, muutokset työtä koskevissa arvoissa ja elämäntapamuutokset). Kolmannessa vaiheessa sisällönanalyysin tuloksia verrattiin BBI-15:n työuupumuspisteisiin pyrittäessä kuvaamaan tutkittavien erilaisia toipumispolkuja. Toipumispolkuluokitusten muodostaminen oli kehämäistä ja itsekorjaavaa: luokkia ja niiden kriteereitä muokattiin aineistoa uudelleen lukemalla, kunnes kaikki yhteen toipumispolkuun luokitellut vastaajat täyttivät samat aiempien analyysivaiheiden perusteella määritellyt kriteerit sekä toisaalta erosivat kaikista muihin toipumispolkuihin luokitelluista vastaajista.

\section{Tulokset}

Kokemus työuupumuksesta ja sen muutos

Seurantatutkimuksessa lähes kaikkien vastaajien BBI-15-kokonaispistemäärät olivat kohonneet kuntoutuksen päättymisen jälkeen, mutta ne olivat kuitenkin edelleen alhaisemmat kuin ennen kuntoutusjakson alkua. Neljän vastaajan työuupumuksen vakavuusluokitus oli pysynyt pitkäaikaisseurannassa samana ja viiden huonontunut. Kokonaispistemäärien perusteella kolme vastaajaa ei enää kärsinyt lainkaan työuupumuksesta, kahden työuupumus oli lievää, kahden kohtalaista sekä kahden vakavaa. Nämä työuupumusluokituksissa tapahtuneet muutokset on esitelty taulukossa 1. On kuitenkin hyvä huomata, että vastaajien oma kokemus työuupumuksesta toipumisesta oli seurantakyselyn avointen kysymysten perusteella näitä BBI-15-luokituksia positiivisempi: vastaajista viisi koki työuupumuksensa helpottuneen, yhden kokemuksissa ei ollut tapahtunut merkittävää muutosta ja vain kolme koki uupumuksensa lisääntyneen kuntoutusjaksoon nähden.

\section{Työuupumuksesta toipumista edistäneet tekijät}

Seurantakyselyn vastausten perusteella löytyi useita tekijöitä, jotka kytkeytyivät tutkittavien hyvinvointiin ja jaksamiseen sekä työssä että yleisesti elämässä. Yhteensä viisi vastaajaa mainitsi työympäristöön liittyviä positiivisia tekijöitä, joita olivat muun muassa vähäisemmät työtunnit, työilmapiirin parantuminen ja esimiehen ymmärrys työuupumusta kohtaan. Kielteisesti hyvinvointiin vaikuttaneita asioita, kuten kiireen, lomautukset sekä yleisen epävarmuuden ja huonon työilmapii- 
rin, mainitsi puolestaan neljä vastaajaa. Vastaajat olivat pyrkineet vaikuttamaan työhönsä liittyviin stressitekijöihin muun muassa työpaikkaa vaihtamalla $(n=4)$ sekä osa-aikaeläkkeelle hakeutumalla $(\mathrm{n}=1)$. Toisaalta myös omiin asenteisiin ja elämäntapoihin liittyvät tekijät nousivat esille tutkittavien vastauksissa. Moni oli kuntoutuksen myötä kiinnittänyt enemmän huomiota työn ja vapaa-ajan väliseen tasapainoon $(n=4)$, lisännyt vapaa-ajan harrastuksia $(\mathrm{n}=6)$ sekä viettänyt enemmän aikaa perheen parissa $(n=6)$. Kuntoutus oli myös muuttanut tutkittavien suhtautumista työuupumukseen: vastaajat kertoivat ymmärtävänsä paremmin työuupumuksen syntyyn johtaneita tekijöitä $(\mathrm{n}=6)$ sekä osaavansa hakea apua jatkossa, mikäli tarvetta ilmenisi (n =4). Lisäksi vastaajat mainitsivat toipumiseen vaikuttaneiksi tekijöiksi kuntoutusryhmästä saadun vertaistuen $(n=8)$ sekä ammattilaisten neuvot terveyden ja elämäntapojen parantamiseksi $(\mathrm{n}=8)$.

\section{Toimijuus ja toipumisen polut}

Työuupumuspistemäärien sekä haastatteluja kyselyaineiston analyysin perusteella tutkittavien joukosta oli eroteltavissa kolme eri ryhmää eli toipumisen polkua, joita vastaajat olivat seuranneet. Nämä ryhmät nimettiin seuraavasti: a) "työuupumuksesta toipuneet" $(\mathrm{n}=3), \mathrm{b})$ "uudestaan uupuneet" $(\mathrm{n}=4)$ ja c) "kovia kokeneet, mutta positiiviseen keskittyvät” ( $\mathrm{n}=2$ ). Ryhmien yhteys työuupumusoireissa tapahtuneisiin muutoksiin on esitelty taulukossa 1.

Näistä ensimmäinen eli "toipuneiden" ryhmä erottui joukosta selkeimmin: heidän kuntoutusjaksolla alkanut hyvä kehityksensä oli jatkunut, eivätkä he kärsineet enää työuupumuksesta sen enempää BBI-15:n kuin seurantakyselyn avoimien vastaustenkaan perusteella. Tähän ryhmään kuuluvien vastaajien asenteissa oli tapahtunut monenlaisia muutoksia kuntoutuksen jälkeen: heidän työhön ja vapaa-aikaan käyttämänsä aika sekä voimavaransa olivat nyt paremmin tasapainossa, he olivat ottaneet vastuuta omasta hyvinvoinnistaan ja kokivat työnsä arvostuksen lisääntyneen. Kaksi toipunutta (T1-2) vastaajaa kuva- si haastattelussa vastuunottoa omasta hyvinvoinnistaan seuraavasti:

T1: "Sillon kun se oli se ensimmäinen [kuntoutus]jakso menny, niin mä niinku heti sillon aloin tekemään niitä asioita, millekä mä voin jotakin. Elikä just se paikkakunnan vaihdos ja sitten sitten tuota, ää, uuden asunnon etsiminen - - sai niinku semmosta potkua, että näin mun pitää nyt tehdä. Ja nimenomaan mun pitää tehdä, että en mä voi sitä odottaa jostakin ulkopuolelta. Mun pitää niinku ottaa siitä vastuu itte."

T2: ”Et kyllähän me ollaan kukin oman onnemme seppiä sillä lailla. Ja sitten tässä fyysisen kunnon kohotuksessa ja ittestähän se pitää lähteä, että tekee sen muutoksen ja tekee ne muutokset ja päättää et näin se on. Että kyllä mä niinku ja sitten on rohkeampi niinku tekemään ja nyt mä tiedän, että kun mä kotiakin menen, että mistä mä haen sitä apua."

Toipuneiden vastaajien ymmärrys työuupumuksen synnystä ja siihen vaikuttavista tekijöistä oli lisääntynyt kuntoutuksen myötä, ja he pyrkivät huolehtimaan omasta hyvinvoinnistaan esimerkiksi liikkumalla, matkustelemalla, harrastamalla kulttuuria sekä viettämällä enemmän aikaa perheen parissa. Näiden vastaajien toimijuutta voisi kuvailla vahvaksi ja aktiiviseksi. Kuntoutuksen päätyttyä uupumuksesta toipuneet luottivat vahvasti omaan työkykyynsä, eivätkä he pitäneet työuupumuksen uusiutumista todennäköisenä. Seurantakyselyssä kaksi toipunutta tutkittavaa kertoi lisäksi työolojensa muuttuneen selkeästi paremmiksi.

Toipuneiden vastakohtana erottui neljä "uudestaan uupunutta" henkilöä, joiden kuntoutusjaksolla alkanut toipuminen ei ollut jatkunut, vaan he kärsivät puolitoista vuotta myöhemmin jälleen vähintään kohtalaisesta työuupumuksesta BBI-15:1lä arvioitaessa. Uudestaan uupuneiksi luokiteltujen kertomus nykyisestä voinnistaan vastasi BBI-15:n an- 
tamaa tietoa. Näitä henkilöitä yhdistivät pitkäaikainen tai jo ennen kuntoutusjaksoa uusiutunut työuupumus sekä huonot työolosuhteet. Kuten toipuneiden henkilöiden, myös uudestaan uupuneiden toimijuus oli kuntoutusjaksolla vahvistunut ja heillä oli tapahtunut asennemuutoksia, kuten esimerkiksi täydellisyyden tavoittelusta luopumista tai elämäntapojen muuttamista terveellisemmiksi. Uudestaan uupuneet painottivat kuitenkin toipuneita kuntoutujia enemmän ympäristöön ja työhönsä liittyviä tekijöitä työuupumuksensa taustalla ja siitä toipumisessa, eli heidän toimijuutensa oli passiivisempaa kuin työuupumuksesta toipuneilla. Yksi uudestaan uupuneista (U1-2) kuvasi muilta saamansa tuen olennaista roolia toipumisprosessissaan seuraavasti:

U1: "[Tytär] muutti sit mun kanssani asumaan - - hän oli sitten aina kotona kun mä tulin ja tietyssä mielessä hän rupes niinku mua rupes potkimaan, et nyt tuota, et äiti mä en jaksa kattella sua tollasena ja et sä oo oikeesti tommonen ja mieti nyt, että et nää kaks tavallaan se työterveyshuolto ja sitten tää hänen potkunsa - - että tietyssä mielessä hän oli mulle semmonen et mä tiesin että mulla on siinä tavallaan tuki, et mun ei tarttekaan yksin - - kyllä se sillä lailla mua paljon, paljon potki eteenpäin."

Kuntoutusjakson jälkeen uudestaan uupuneet olivat edelleen joutuneet kamppailemaan työhönsä liittyvien stressitekijöiden kanssa. Heitä voisikin vaihtoehtoisesti kuvata "olosuhteiden uhreiksi", sillä Banduran (2000) teoriaa mukaillen he eivät todennäköisesti olleet saaneet ympäristöstään riittävästi tukea orastavalle toimijuudelleen. Toisaalta nämä tutkittavat pitivät jo kuntoutuksen lopulla uudestaan uupumistaan todennäköisempänä kuin toipumisen polulla pysyneet henkilöt. Yksi vastaajista kuvasi tilannettaan seuraavasti:

U2: "Toivon hirveesti, että pystyisin välttämään [uupumuksen uusiutumisen], mutta että... kun näitä nyt on ollu näitä näitä uusintoja niin vaikka mulla nyt on kuitenkin semmonen paras tunne mitä on koskaan ollu näiden tuota sairastumisten aikana silleen. Mä toivon että mä pystyn välttämään, mutta en mä uskalla sanoa.”

"Kovia kokeneet, mutta positiiviseen keskittyvät” henkilöt osoittivat kuntoutusjaksolla vahvan toimijuuden merkkejä, joita olivat muun muassa työpaikan vaihdos, työhön liittyvät asennemuutokset sekä vastuunotto omasta hyvinvoinnista. Myöhemmin seurantatutkimuksessa he molemmat kärsivät kuitenkin jälleen lievästä työuupumuksesta BBI15:llä mitattuna. Tähän on todennäköisesti syynä heidän kuntoutusjakson jälkeen kohtaamansa stressitekijät, joita olivat muun muassa läheisen sairaus, huono taloustilanne ja pitkät työmatkat. Toisin kuin uudestaan uupuneet henkilöt, kovia kokeneet mutta positiiviseen keskittyvät näkivät kuitenkin tilanteensa huomattavasti aiempaa valoisampana, eivätkä he kokeneet kärsivänsä enää työuupumuksesta. Seurantakyselyn perusteella näyttäisi siltä, että näiden henkilöiden toimijuus oli vaikeuksista huolimatta säilynyt vahvana ja sen ansiosta he pystyvät keskittymään elämän positiivisiin puoliin haasteista huolimatta. Toinen heistä (K1) kuvasi seurantakyselyssä tilannettaan seuraavasti:

K1: "Ajoittain olen ollut todella väsynyt valvottuani lapsen kanssa öitä - huolehdin työpäivän aikana lapseni hyvinvoinnista kännykän avulla eli keskittyminen työhön on välillä huonoa - - On pakko jaksaa, koska talous ei anna periksi jäädä pois töistä.

[Kuntoutuksen myötä] ymmärsin, että voin toipua ja että syy ei ole vain minussa. Voin kuitenkin itse vaikuttaa toipumiseeni ja jopa muuttaa huonoja olosuhteita äänestämällä jaloilla. - - Jämäkkyyden harjoittelu oli tärkeää. Nyt osaan sanoa ei, en aina jaksa miellyttää muita vaan pyrin ajattelemaan myös omaa hyvinvointiani." 


\section{Pohdinta}

\section{Päätulokset}

Tässä artikkelissa selvitettiin pitkäaikaista työuupumuksesta toipumista ja siihen yhteydessä olevia tekijöitä sekä laadullisten että määrällisten tutkimusmenetelmien avulla. Tutkimukseen valittiin mukaan henkilöitä, jotka olivat alun perin hyötyneet kuntoutuksesta BBI-15-työuupumuskyselyn perusteella. Puolitoista vuotta tämän kuntoutuksen päättymisen jälkeen toteutetun seurantatutkimuksen tulokset kuitenkin osoittivat, että työuupumusoireiden pitkäaikainen kehityskulku oli hyvin yksilöllistä. Yleisellä tasolla näyttäytyi, että kaikkien vastaajien työuupumuspisteet olivat hieman nousseet kuntoutuksen päättymisen aikaisesta tilanteesta. Yksityiskohtainen tarkastelu kuitenkin osoitti, että vain viiden vastaajan työuupumuksen vakavuusluokat (Näätänen ym. 2003) olivat muuttuneet. Nämä muutokset olivat tapahtuneet kielteiseen suuntaan eli työuupumuksen kokemukset olivat lisääntyneet. Neljän vastaajan työuupumusluokitus oli puolestaan pysynyt samana, ja heistä kolmen voidaan katsoa toipuneen uupumuksesta täysin 1,5 vuotta kuntoutuksen päättymisen jälkeen. Mielenkiintoista kuitenkin on, että kysyttäessä tutkittavien omaa kokemusta työuupumusoireilun tasosta ja sen muutossuunnasta neljä koki työuupumuksensa helpottuneen ja vain kolme koki uupumuksensa pahentuneen. Kahden vastaajan kokemuksissa ei puolestaan ollut tapahtunut merkittävää muutosta.

Puolentoista vuoden seurannassa vastaajien oma kokemus toipumisestaan näyttäytyi siis myönteisempänä kuin tutkimuksessa käytetyn BBI-15-kyselyn pistemäärät. Tämä saattaa osaltaan johtua BBI-15:n mittaustavasta, joka on herkkä sen hetkiselle työkuormitukselle. Avoimissa kysymyksissä tutkittavat puolestaan arvioivat oireiluaan pitkällä aikavälillä ja vertasivat nykyvointiaan kuntoutusta edeltävään aikaan, jolloin heidän työuupumuksensa oli korkeammalla tasolla. Toisaalta kuntoutuksen seurantajaksolla kerätyn haastattelutiedon perusteella tutkittavien kokemukset omasta voinnistaan olivat varsin myön- teisiä jo kuntoutuksen perus- ja seurantajakson välillä - poikkeuksena ne henkilöt, jotka seurantatutkimuksessa luokiteltiin uudestaan uupuneiksi. Tämän tuloksen perusteella voidaan todeta, että kuntoutustutkimuksessa kuntoutujien oman toipumiskokemuksen tiedustelu on yhtälailla tärkeää kuin strukturoitujen menetelmien käyttö.

Kaikki tutkimukseen osallistuneet henkilöt olivat hyötyneet kuntoutuksesta lyhytaikaisesti, mutta seurantatutkimuksen perusteella kuntoutuskurssilla alkanut myönteinen kehitys ei kuitenkaan ollut jatkunut kaikilla toivotulla tavalla. Aineistosta oli löydettävissä tähän monia syitä. Ensinnäkin tutkittavien vastauksista nousi esiin työhön liittyvien tekijöiden iso merkitys työuupumuksen uusiutumisessa tai siitä toipumisessa. Tutkittavat olivat pyrkineet vaikuttamaan työhönsä liittyviin stressitekijöihin muun muassa työpaikkaa vaihtamalla, ja kohentuneet työolot näyttivätkin edistäneen vastaajien toipumisprosessia. Vastaajat eivät kuitenkaan olleet pystyneet vaikuttamaan kaikkiin työn ongelmakohtiin, kuten esimerkiksi esimiehen toimintaan tai lomautuksista johtuvaan epävarmuuteen ja kireään työtahtiin. Nämä tekijät olivatkin vastaavasti yhteydessä työuupumuksen uusiutumiseen.

Myös monet työntekijään itseensä liittyviä tekijät ovat tutkitusti yhteydessä työuupumukseen (Alarcon ym. 2009; Demerouti 2014) ja tutkittavien mukaan heidän oma asenteensa sekä elämäntapansa olivatkin vaikuttaneet olennaisesti uupumuksesta toipumiseen. Yhden vastaajan sanoin toipumiseen johtanut muutos oli tapahtunut nimenomaan "korvien välissä”, sillä hänen työnkuvansa oli säilynyt muuttumattomana. Toinen vastaaja kertoi puolestaan tajunneensa, että "mikäli hän ei itse tee muutoksia elämässään, ei niitä tee kukaan muukaan". Vastaajat kertoivat kiinnittäneensä kuntoutuksen myötä enemmän huomiota esimerkiksi terveellisiin elämäntapoihin sekä perheen ja ystävien kanssa vietettyyn laatuaikaan. Itse kuntoutuskurssiin liittyneistä tekijöistä tutkittavat mainitsivat vaikuttavimmiksi ryhmästä saadun vertaistuen sekä ammattilaisten neuvot hyvinvoinnin edistämiseksi. 
Toimijuuden vahvistaminen on kuntoutuksen keskeisiä tavoitteita (Järvikoski \&t Härkäpää 2011), ja tavoite näyttäisi täyttyvän hyvinvoinnin polulla pysyneiden kuntoutujien osalta. Vastaajien kertomusten mukaan kuntoutusjakso oli merkittävästi vahvistanut heidän henkilökohtaista toimijuuttaan kannustamalla muun muassa elämäntapamuutoksiin, sosiaalisiin suhteisiin panostamiseen sekä työn ja vapaa-ajan selkeämpään erottamiseen. Henkilökohtaisen toimijuuden vahvistuminen selittänee myös sitä huomionarvoista havaintoa, että tutkittavat selkeästi kokivat kuntoutuksen hyödyttäneen heitä, vaikka edistys ei kaikkien tapauksissa näkynytkään BBI-15-arviointimenetelmällä mitattaessa. Kuntoutujat pitivät kuitenkin henkilökohtaista toimijuutta lisänneiden tekijöiden ohella kuntoutuksen merkittävimpänä antina toisilta kuntoutujilta sekä työntekijöiltä saatua tukea, mikä viittaa läheistoimijuuden merkitykseen. Myös kuntoutujien toipumispolkujen tarkempi analyysi viittaa siihen, että paras pitkäaikaistulos kuntoutuksesta saadaan, kun vahvaan henkilökohtaiseen toimijuuteen yhdistyvät suotuisat ympäristötekijät. Havainnot vastaavat Banduran (2000) teoriaa toimijuuden rakentumisesta, joka ottaa huomioon läheis- ja kollektiivisen toimijuuden merkityksen ja joka toisaalta kuvaa, kuinka suotuisat ympäristötekijät vahvistavat henkilökohtaista toimijuutta ja synnyttävät myönteisen hyvinvoinnin kehän. Toisaalta "kovia kokeneiden, mutta positiiviseen keskittyvien" kuntoutujien kokemukset viittaavat siihen, että vahva toimijuus suojaa uupumuksen uusiutumiselta myös hankalissa elämäntilanteissa - ainakin silloin, kun arviona käytetään yksilön omaa kokemusta.

Vaikka kaikilla tutkimukseen osallistuneilla kuntoutujilla oli havaittavissa henkilökohtaisen toimijuuden vahvistumista kuntoutusjakson aikana ja kaikki myös kokivat hyötyneensä kuntoutuksesta, osa kärsi kuitenkin työuupumuksen oireista 1,5 vuotta myöhemmin."Uudestaan uupuneille" oli tyypillistä, että heidän työuupumuksensa oli kuntoutuksen alkaessa vakavampaa ja/tai pitkäkestoisempaa. Nämä henkilöt myös kokivat nykyisen työtilanteensa huonoksi ja uuvut- tavaksi. Mukana oli henkilö, joka oli jäänyt työttömäksi jo ennen kuntoutusjakson alkua ja jolle kuntoutuskurssi ei siis välttämättä ollut alun perinkään oikea tukimuoto. On varsin ymmärrettävää, että hankala lähtötilanne sekä uudet vaikeudet ovat osaltaan johtaneet siihen, että näiden vastaajien työuupumus oli lisääntynyt pitkäaikaisseurannassa. Se osoittaa, että kuntoutusjaksolla alkanut henkilökohtaisen toimijuuden vahvistuminen ei yksin riitä pitämään kuntoutujia toipumisen polulla, vaan työn stressitekijöillä on merkitystä työuupumuksen uusiutumisessa. Havainto myötäilee niitä tutkimustuloksia, joiden mukaan työssä tai työpaikalla toteutetut muutokset vahvistavat uupumusinterventioiden vaikuttavuutta (Härkäpää 2002).

Toisaalta tutkimuksen tulokset osoittavat, että ympäristön stressitekijät eivät automaattisesti johda työuupumuksen uusiutumiseen: näyttäisi siltä, että "kovia kokeneiden, mutta positiiviseen keskittyvien" henkilöiden vahvistunut toimijuus suojasi stressitekijöiltä ja johti yhtä myönteiseen kokemukseen omasta voinnista kuin kokonaan työuupumuksesta toipuneillakin. Näitä kahta toipumisen polulla pysynyttä ryhmää yhdisti omien ajatusten ja toiminnan aktiivinen reflektointi, vahva pystyvyysusko sekä aktiiviset muutokset käyttäytymisessä. Kyseisiä piirteitä voidaan kuvata vahvaksi henkilökohtaiseksi toimijuudeksi. Vaikka uudestaan uupuneiden ryhmällä oli kuntoutuksen perusjakson jälkeen nähtävissä samantapaisia muutoksia, on kuitenkin todennäköistä, että pitkäaikaisesta tai vakavasta työuupumuksesta kärsivät henkilöt tarvitsisivat enemmän tukea ympäristöltään, jotta myönteiset muutokset olisivat pysyviä. Oletus työuupumuskuntoutujien tuen tarpeesta mukailee Banduran $(2000,2012)$ sosiokognitiivista käsitystä, jonka mukaan henkilökohtaisen toimijuuden oletetaan kehittyvän vuorovaikutuksessa ympäristötekijöiden, erityisesti sosiaalisten suhteiden ja vuorovaikutuksen, kanssa.

Yhteenvetona voidaan todeta, että kuntoutujien henkilökohtainen toimijuus ja erityisesti sen keskeinen osatekijä pystyvyysusko oli merkittävässä roolissa työuupumuksesta 
toipumisessa. Tätä korostaa tutkimuksen havainto, jonka mukaan tutkittavien kuntoutuksen seurantajakson lopussa esittämä arvio omasta tulevaisuuden pärjäämisestään ja toipumisestaan ennusti erittäin hyvin heidän puolitoista vuotta myöhempää toipumispolkuaan. On mahdollista, että tutkittavien vähäinen usko omiin toipumismahdollisuuksiinsa on johtanut heikkoon toimijuuteen ja sitä kautta uudestaan uupumiseen, vaikka syyseuraussuhteiden suuntaa ei tässä tutkimusasetelmassa olekaan mahdollista osoittaa.

\section{Tutkimuksen rajoitukset}

Tutkimukseen osallistui vain yhdeksän henkilöä, ja siksi tulosten yleistettävyys on varsin rajallista. Tämä tutkimus tulisikin ymmärtää ensisijaisesti tapaustutkimuksena. Tutkimuksen vahvuutena on monipuolisten aineistonkeruumenetelmien käyttö, mikä mahdollisti moniulotteisen kuvan saamisen työuupumuskuntoutuksen vaikuttavuudesta sekä kuntoutujien yksilöllisistä toipumisprosesseista. Aineistosta erottui varsin selkeästi kolme erilaista toipumispolkua, joita oli mahdollista ymmärtää paitsi työolojen, myös kuntoutujien henkilökohtaisen toimijuuden kautta.

Työuupumuskuntoutuksen vaikutusmekanismeista tarvitaan jatkotutkimuksia, sillä työuupumuksella on kauaskantoisia seurauksia uupuneiden henkilökohtaiseen hyvinvointiin (Ahola \&t Hakanen 2014). Myös tässä tutkimuksessa havaittujen toipumispolkujen tunnistaminen isommalla aineistolla olisi tarpeen. Samoin toimijuutta ja sen yhteyttä työuupumuksesta toipumiseen olisi hyvä kartoittaa jatkotutkimuksilla, jotka olisivat suurempia otoskooltaan ja joiden asetelma mahdollistaisi kuntoutujien henkilökohtaisessa toimijuudessa tapahtuvien muutosten tarkemman seurannan eri ajankohdissa sekä tulosten laajemman yleistettävyyden. Myös toimijuuden eri muotojen kattavampi huomiointi on tärkeää, sillä henkilökohtaiseen toimijuuteen rajoittuminen saattaa johtaa liian yksilökeskeiseen ja jopa yksilöä syyllistävään näkemykseen työuupumuksen synnystä ja toipumisprosessista.

\section{Johtopäätökset}

Kuntoutuksen tuloksellisuuteen vaikuttavat luonnollisesti monet tekijät, mutta tämän tutkimuksen tulosten perusteella kuntoutujien orastavan henkilökohtaisen toimijuuden tukeminen on haaste, johon kuntouttamisella kannattaisi pyrkiä vastaamaan. Aineistomme perusteella vastaajien toimijuutta saadaan kyllä heräteltyä kuntoutuksen aikana, mutta ongelmana on se, kuinka toimijuuden vahvistumisesta saataisiin pysyvää siten, että kuntoutujat pystyisivät onnistuneesti kohtaamaan tulevaisuuden haasteet.

Tutkimukseen osallistuneista yhdeksästä vastaajasta moni eli viisi henkilöä toivoi ylimääräistä seurantajaksoa esimerkiksi vuoden kuluttua kuntoutuksen päättymisen jälkeen. Vastaajien mukaan heidän toipumistaan edistäisi se, että olisi jotain konkreettista, mitä odottaa kuntoutuksen päättymisen jälkeen. Se voisi kannustaa kuntoutujia muun muassa oman olon tarkkailuun sekä elämäntapamuutoksien ylläpitoon. Nämä seikat antavat viitteitä läheis- ja kollektiivisen toimijuuden (Bandura 2000) merkityksestä kuntoutuksessa. Myös näitä toimijuuden muotoja olisi syytä kartoittaa hyödyntäen monimenetelmällisiä tutkimusasetelmia. Lisäksi tutkimus osoitti, että kuntoutujien oma uskomus pärjäämisestään kuntoutusjaksojen jälkeen ennusti hyvin heidän toipumistaan tai uudelleen uupumistaan pitkässä seurannassa. Tätä havaintoa voisi hyödyntää konkreettisesti työuupumuskuntoutuksessa ja mahdollisia lisäjaksoja tai tukitoimia kohdistaa niihin, jotka itse pitävät uupumuksensa uusiutumista todennäköisimpänä.

\section{Tiivistelmä}

Tutkimuksen tarkoituksena oli selvittää työuupumuksesta toipumisen kehityspolkuja ja näihin yhteydessä olevia tekijöitä 1,5 vuoden seurannan aikana. Erityisenä kiinnostuksen kohteena oli toimijuus ja sen rakentumisen yhteys työuupumuksesta toipumiseen. Tutkimusaineisto koostui Kuntoutus Peurungan Virveli-kuntoutus- 
kursseille osallistuneista ja kuntoutuksesta lähtökohtaisesti hyötyneistä henkilöistä ( $\mathrm{n}=9$ ). Kyseessä on tapaustutkimus, jossa näiden henkilöiden toipumisprosessia tutkittiin monipuolisesti sekä haastattelun että kyselyiden avulla. Tulokset osoittivat, että monet työympäristöön liittyvät tekijät olivat yhteydessä toipumisprosessiin, mutta ne eivät yksinään selittäneet sitä, oliko henkilöiden työuupumus uusiutunut vai ei. Aineistosta löydettiin kolme erilaista kehityspolkua, jotka olivat "työuupumuksesta toipuneet", "uudestaan uupuneet" ja "kovia kokeneet, mutta positiiviseen keskittyvät”. Kuntoutujien toipumispolkuun näyttäisi tämän tutkimuksen perusteella olevan yhteydessä heidän kokemansa henkilökohtainen toimijuus, joka ilmeni erityisesti uskona omaan pärjäämiseen kuntoutusjakson lopussa. Näihin tekijöihin olisikin hyvä kiinnittää huomiota sekä jatkotutkimuksissa että työuupumusinterventioiden kehitystyössä, jotta kuntoutuksen vaikuttavuutta voitaisiin tehostaa.

Avainsanat: työuupumus, kuntoutus, toimijuus, seurantatutkimus, monimenetelmällisyys

\section{Abstract}

The individual recovery paths from job burnout: a mixed methods case study on the long-term impact of a rehabilitation intervention.

The purpose of this study was to examine the developmental paths of burnout recovery and factors associated with it during a 1.5-year follow-up period. A special interest of the study was in agency and whether it is connected to burnout recovery. The study sample $(n=9)$ included people, who had benefitted from a rehabilitation period arranged earlier in Peurunka Rehabilitation Centre. This research was a case study, which was based on data collected by interviews and questionnaires in analyzing the recovery process of the participants. Analysis showed that many job-related factors were connected to the recovery process, but none of them was able to explain alone whether participants' burnout had relapsed or not. Three different recovery paths were found among the sample: "recovered participants", "relapsed participants" and "participants with difficult experiences but positive mindset". The results indicate that the personal agency of the people participating in rehabilitation is connected to their recovery paths. Agency was manifested, for example, in participants' self-efficacy estimates at the end of the rehabilitation period. These factors should be paid more attention in future studies as well as in developing burnout interventions in order to improve the effectiveness of burnout rehabilitation.

Keywords: burnout, rehabilitation, agency, follow-up study, mixed methods

Heli Siltala, PsM, tohtorikoulutettava, psykologian laitos, Jyväskylän yliopisto

\section{Anne Mäkikangas, PsT, dosentti, psykologian} laitos, Jyväskylän yliopisto

\section{Marja Hätinen, PsT, työterveyspsykologi, työ-ja organisaatiopsykologian erikois- psykologi, Terveystalo Jyväskylä}

Ulla Kinnunen, PsT, professori, yhteiskunta- ja kulttuuritieteiden yksikkö, Tampereen yliopisto

Mika Pekkonen, LT, johtava ylilääkäri, Kuntoutus Peurunka, Laukaa

\section{Lähteet}

Ahola K, Hakanen J (2014) Burnout and health. Teoksessa Leiter MP, Bakker AB, Maslach C (toim.) Burnout at work: A psychological perspective. Hove, East Sussex: Psychology Press. 10-31.

Alarcon G, Eschleman KJ, Bowling NA (2009) Relationships between personality variables and burnout: A meta-analysis. Work \&t Stress 23, 3, 244263. 
Awa WL, Plaumann M, Walter U (2010) Burnout prevention: A review of intervention programs. $\mathrm{Pa}-$ tient Education and Counseling 78, 2, 184-190.

Bandura A (2000) Exercise of human agency through collective efficacy. Current Directions in Psychological Science 9, 3, 75-78.

Bandura A (2006) Toward a psychology of human agency. Perspectives on Psychological Science 1, 2, 164-180.

Bandura A (2012) On the functional properties of perceived self-efficacy revisited. Journal of Management 38, 1, 9-44.

Bernier D (1998) A study of coping: Successful recovery from severe burnout and other reactions to severe work-related stress. Work \& Stress: An International Journal of Work, Health \& Organisations $12,1,50-65$.

Demerouti E (2014) Individual strategies to prevent burnout. Teoksessa Leiter MP, Bakker AB, Maslach C (toim.) Burnout at work: A psychological perspective. Hove, East Sussex: Psychology Press. 10-31.

Fjellman-Wiklund A, Stenlund T, Steinholtz K, Ahlgren C (2010) Take charge: patients' experiences during participation in a rehabilitation programme for burnout. Journal of Rehabilitation Medicine 42, 475-481.

Härkäpää K (2002) Varhaiskuntoutuksen vaikuttavuus. Teoksessa: Aalto AM ym. (toim.) Kannattaako kuntoutus? Asiantuntijakatsaus eräiden kuntoutusmuotojen vaikuttavuudesta. Raportteja nro 267, Helsinki: STAKES. 29-44.

Hätinen M (2008) Treating job burnout in employee rehabilitation: Changes in symptoms, antecedents and consequences. Jyväskylä: Jyväskylän Yliopistopaino.

Hätinen M, Kinnunen U, Mäkikangas A, Kalimo R, Tolvanen A, Pekkonen M (2009) Burnout during a long-term rehabilitation: comparing low burnout, high burnout - benefited, and high burnout - not benefited trajectories. Anxiety, Stress, \& Coping 22, 3, 341-360.

Hätinen M, Kinnunen U, Pekkonen M, Kalimo R (2007) Comparing two burnout interventions: Perceived job control mediates decreases in burnout. International Journal of Stress Management 14, 3, 227-248.

Hätinen M, Mäkikangas A, Kinnunen U, Pekkonen M (2013) Recovery from burnout during a one-year rehabilitation intervention with six-month follow-up: Associations with coping strategies. International Journal of Stress Management 20, 4, 364-390.

Järvikoski A, Härkäpää K (2011) Kuntoutuksen pe- rusteet. Näkökulmia kuntoutukseen ja kuntoutustieteeseen. Helsinki: WSOY.

Järvikoski A, Härkäpää K, Salminen A-L (2015a). Kuntoutuksen teorioista ja ICF-mallista. Kuntoutus 38, 2, 18-32.

Järvikoski A, Martin M, Autti-Rämö I, Härkäpää K (2013) Shared agency and collaboration between the family and professionals in medical rehabilitation of children with severe disabilities. International Journal of Rehabilitation Research 36, $1,30-37$.

Järvikoski A, Puumalainen J, Härkäpää K (2015b) Client participation in medical rehabilitation for adults with severe disabilities. Scandinavian Journal of Disability Research 17, 3, 240-257.

Kalimo R, Hakanen J, Toppinen-Tanner S (2006) Maslachin yleinen työuupumuksen arviointimenetelmä MBI-GS. Helsinki: Työterveyslaitos.

Kansaneläkelaitos (2008) Kelan laitosmuotoisen kuntoutuksen standardi, versio 15/2008, täsmennetty 5.12.2008. [Verkkojulkaisu]. [Viitattu 31.10.2016]. Saatavissa: http://www.kela.fi/in/internet/liite. nsf/(WWWAllDocsById)/8CB38AF6DEC218EAC2 25753D00425B50/\$file/standardi_15.pdf

Kuntoutus Peurunka (2010) Työohje Virveli-kurssi.

Lloyd J, Bond FW, Flaxman PE (2013) The value of psychological flexibility: Examining psychological mechanisms underpinning a cognitive behavioural therapy intervention for burnout. Work $\&$ Stress 27, 2, 181-199.

Maslach C, Schaufeli WB, Leiter MP (2001) Job burnout. Annual Review of Psychology 52, 1, 397422.

Mäkikangas A, Kinnunen U (2016) The person-oriented approach to burnout: A systematic review. Burnout Research 3, 11-23.

Näätänen P, Aro A, Matthiesen SB, Salmela-Aro K (2003) Bergen Burnout Indicator 15. Helsinki: Edita.

Salminen S, Mäkikangas A, Hätinen M, Kinnunen U, Pekkonen M (2015) My well-being in my own hands: Experiences of beneficial recovery during burnout rehabilitation. Journal of Occupational Rehabilitation 25, 4, 733-741.

Suvisaari J, Ahola K, Kiviruusu 0, Korkeila J, Lindfors 0 ym. (2012) Psyykkiset oireet ja mielenterveyden häiriöt. Teoksessa S Koskinen, A Lundqvist, N Ristiluoma (toim.) Terveys, toimintakyky ja hyvinvointi Suomessa 2011. Raportti 68, Helsinki: Terveyden ja hyvinvoinnin laitos. 96-107.

Tuomi J, Sarajärvi A (2009) Laadullinen tutkimus ja sisällönanalyysi (5. uud. laitos.). Helsinki: Tammi. 